\title{
Sustav trošarina u Hrvatskoj bliži europskom sustavu
}

\author{
DANIJELA KULIŠ Institut za javne financije
}

$S$ ciljem ugradnje europskih trošarinskih instituta u zakonodavstvo Republike Hrvatske (RH) $i$ usklađivanjem s minimalnim visinama stopa trošarina propisanih EU direktivama, u veljači je objavljen novi Zakon o trošarinama (ZOT). Zakon je stupio na snagu 2. ožujka s izuzetkom određenih odredbi koje će se primjenjivati od dana primanja u Europsku uniju. Prvi dio ZOT-a donosi temeljne odredbe trošarinskog sustava, drugi se odnosi na oporezivanje harmoniziranih trošarinskih proizvoda, a treći sadrži prekršajne, postupovne te prijelazne i završne odredbe.

Zakonom se od I. ožujka 20I3. na teritoriju RH uvodi elektronički Sustav kontrole kretanja trošarinskih proizvoda (Excise Movement Control System - EMCS), a s danom pristupa EU-u uspostavlja se i između RH i drugih država članica EU-a. Sustav omogućuje elektroničku razmjenu informacija između ovlaštenih gospodarskih subjekata i nadležnih carinskih i poreznih tijela $u$ zemljama članicama, $u$ cilju praćenja kretanja trošarinskih proizvoda $u$ sustavu odgode plaćanja trošarinskih davanja․ EMCS zamjenjuje papirnati prateći trošarinski dokument elektronskim.

\section{Unošenje trošarinskih proizvoda}

Ukoliko fizička osoba unosi i sama prevozi trošarinske proizvode za osobne, a ne za komercijalne svrhe - koji su već pušteni u potrošnju u drugoj državi članici - pod određenim uvjetima ne nastaje obveza plaćanja trošarine.

Uneseni trošarinski proizvodi nisu namijenjeni za komercijalne svrhe ako njihove količine ne prelaze: 800 komada cigareta; 400 komada cigarilosa; 200 komada cigara; I kilogram duhana za pušenje; ro litara jakog alkoholnog pića, 20 litara međuproizvoda; 90 litara vina, uključujući najviše 6o litara pjenušavog vina; IIo litara piva. Obveza plaćanja trošarine nastaje za svaki prijevoz energenata, osim prijevoza pogonskog goriva u standardnim spremnicima motornih vozila ili $u$ prikladnim prenosivim kanistrima za rezervno gorivo zapremnine do io litara.

\footnotetext{
${ }^{\text {I }}$ Sustav odgode plaćanja trošarine primjenjuje se na primanje, proizvodnju, preradu (obradu), skladištenje, izvođenje drugih radnji s trošarinskim proizvodima i otpremanje trošarinskih proizvoda u kojem je obveza plaćanja trošarine odgođena, a koji nisu obuhvaćeni carinskim sustavom odgode.
} 
U nastavku se prikazuje oporezivanje alkohola i alkoholnih pića, duhanskih prerađevina te energenata i električne energije. Prikaz obuhvaća sadašnji sustav oporezivanja, promjene koje nastupaju ulaskom u EU i usklađenja koja se imaju provesti u sljedećim godinama. Premda su $\mathrm{u}$ harmoniziranom sustavu EU-a propisane minimalne stope i oporezivi proizvodi, među zemljama još uvijek postoje znatne razlike. Radi dobivanja okvirne slike prikazuju se minimalno propisane i stvarne stope koje se primjenjuju u pojedinim zemljama EU-a i u RH.

\section{TROŠARINE NA ALKOHOL I ALKOHOLNA PIĆA}

Visina trošarine na alkohol i alkoholna pića nije promijenjena novim Zakonom. Sadašnje stope u RH na višoj su razini od minimalno propisanih u EU-u i što se tiče europskih propisa ne bi se trebale mijenjati. Pristupanjem EU-u ukidaju se količinska ograničenja za komercijalnu proizvodnju izvan sustava odgode plaćanja trošarine. Proizvođači koji u komercijalne svrhe proizvode alkohol, međuproizvode i ostala pića dobivena vrenjem, moći će proizvoditi, odnosno poslovati i izvan trošarinskih skladišta (čl. 69.) bez polaganja instrumenta osiguranja plaćanja trošarine, što nije omogućeno ostalim proizvođačima trošarinskih proizvoda.

U proizvodnji i preradi neprehrambenih proizvoda, oslobođeni korisnik trošarinskih proizvoda ne plaća trošarinu na etilni alkohol koji je djelomično denaturiran propisanim sredstvima.

\section{Tablica I.}

\section{Stope trošarina na alkohol i alkoholna pića u Hrvatskoj i Europskoj uniji}

\begin{tabular}{|c|c|c|c|}
\hline Trošarinski proizvod & Visina trošarine u Hrvatskoj & $\begin{array}{l}\text { Minimalna trošarina } \\
\text { u EU (u eurima) }\end{array}$ & $\begin{array}{l}\text { Minimalna EU } \\
\text { trošarina }(\mathbf{u ~ k n})\end{array}$ \\
\hline Pivo & $\begin{array}{l}\text { 40 kn za I\% volumnog udjela stvarnog } \\
\text { alkohola u hektolitru gotovog proizvoda } \\
\text { (hl/o alc) }\end{array}$ & $\begin{array}{l}\mathrm{I}, 87 € \mathrm{hl} /{ }^{\circ} \text { alc } \\
\mathrm{o}, 748 € \mathrm{hl} /{ }^{\circ} \mathrm{Pato}\end{array}$ & $\begin{array}{l}\mathrm{I} 3,89 \mathrm{kn} \mathrm{hl} /{ }^{\circ} \text { alc } \\
5,55 \mathrm{kn} \mathrm{hl} /{ }^{\circ} \text { Plato }\end{array}$ \\
\hline Mirna vina & o kn/hl gotovog proizvoda & $o €$ & $\mathrm{o} \mathrm{kn} / \mathrm{hl}$ \\
\hline Pjenušava vina & o kn/hl gotovog proizvoda & $o €$ & $\mathrm{o} \mathrm{kn} / \mathrm{hl}$ \\
\hline $\begin{array}{l}\text { Ostala pića dobivena } \\
\text { vrenjem, osim piva i vina }\end{array}$ & o kn/hl gotovog proizvoda & $o €$ & $\mathrm{o} \mathrm{kn} / \mathrm{hl}$ \\
\hline Međuproizvodi & $\begin{array}{l}\text { 800 kn/hl gotovog proizvoda } \\
\left(\geq 15 \% \mathrm{vol} /{ }^{\circ} \text { alc. }\right) \\
500 \mathrm{kn} / \mathrm{hl} \text { gotovog proizvoda } \\
\left.\text { (<15\% vol/ }{ }^{\circ} \text { alc. }\right)\end{array}$ & $45 € / \mathrm{hl}$ & $334, \mathrm{I} 5 \mathrm{kn} / \mathrm{hl}$ \\
\hline Etilni alkohol & $5.300 \mathrm{kn} / \mathrm{hl}$ čistog alkohola & $550 € /$ hl čistog alkohola & $4.084,03 \mathrm{kn} / \mathrm{hl}$ \\
\hline
\end{tabular}

Napomena: Preračunato prema tečaju ECB (OJ C 296, 2. Io. 2012.), I euro iznosi 7,4255 kuna.

Izvor: European commission (2013a); Zakon o trošarinama.

Svaki alkoholni proizvod se u RH oporezuje jednom stopom, dok u EU-u za sve kategorije proizvoda postoji jedna ili više općih i sniženih stopa. Općih stopa može biti i više, primjerice kod piva, gdje stope ovise o koncentraciji sladovine ili udjelu alkohola. Snižene stope ovise o proizvedenoj količini, a primjenjuju se na pivo nezavisnih malih proizvođača s godišnjom proizvodnjom do $200.000 \mathrm{hl}$ (stopa ne može biti niža od 50\% opće stope). U ZOT-u nisu određene posebne stope za male proizvođače piva. Pivo s manjim udjelom alkohola (do 2,8\%) oporezuje se u EU-u sniženim stopama, ovisno o udjelu alkohola. Iako je stopa trošarine na pivo (5,4 eura/hl) u Hrvatskoj mjerena udjelom alkohola gotovo $65 \%$ viša od minimalne, nižu stopu od hrvatske imaju samo Litva (2,46 eura/hl), Latvija (3,I3 eura/hl) i Slovačka (3,59 eura/hl). Stope trošarine na pivo mjerene udjelom alkohola najviše su u Finskoj, Ujedinjenom Kraljevstvu i Švedskoj. 
Grafikon I. prikazuje visinu stopa na pivo u zemljama EU-a po kriterijima visoke koncentracije sladovine i udjela alkohola (I ${ }^{\circ}$ Plato ili $4,8 \%$ alkohola po hektolitru), što znači da se u tim zemljama primjenjuju i niže stope. Prema ovim kriterijima, stopa u Hrvatskoj je najniža jer se pivo oporezuje samo jednom stopom i prema samo jednom kriteriju (I\% volumnog udjela stvarnog alkohola $u$ hektolitru gotovog proizvoda).

\section{Grafikon I.}

Stope trošarina na pivo u zemljama Europske unije, 20I2/2013. (u eurima)

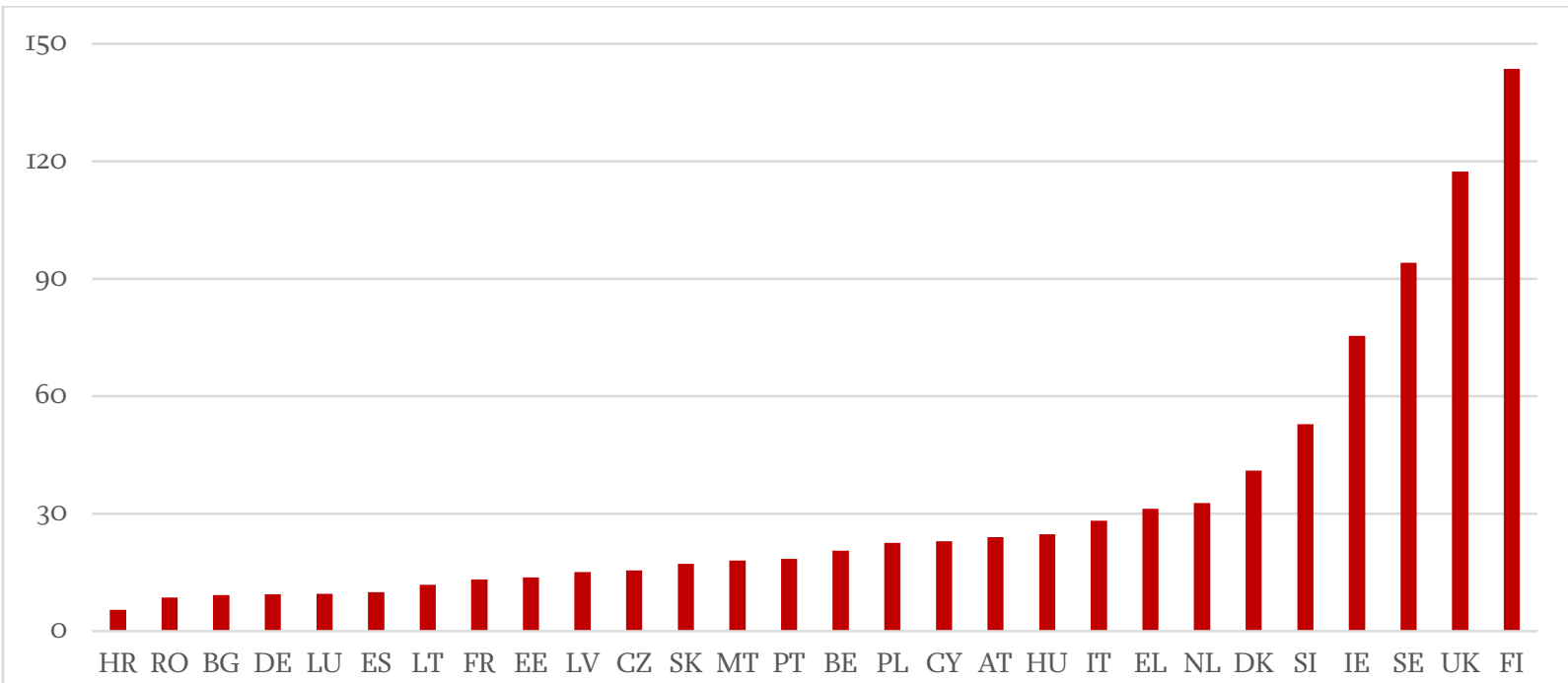

Napomena: AT-Austrija, BE-Belgija, BG-Bugarska, GY-Cipar, CZ-Češka, DE-Njemačka, DK-Danska, EE-Estonija, EL-Grčka, ESŠpanjolska, FI-Finska, FR-Francuska, HU-Mađarska, IE-Irska, IT-Italija, LT-Litva, LU-Luksemburg, LV-Latvija, MT-Malta, NLNizozemska, PL-Poljska, PT-Portugal, RO-Rumunjska, SE-Švedska, SI-Slovenija, SK-Slovačka, UK-Velika Britanija.

Izvor: The Brewers of Europe (20I2); Zakon o trošarinama.

Na vino su u EU-u propisane opće i snižene stope. Većina zemalja primjenjuje opću nultu stopu na vina i u manjoj mjeri na pjenušava vina. Za primjenu nulte stope na mirna vina odlučila se većina zemalja EU-a ${ }^{2}$, dok u zemljama visokog poreznog opterećenja alkohola (Švedska, Finska, Irska, UK) stope variraju od 200 do preko 500 eura/hl.

U usporedbi sa zemljama EU-a, stopa na etilni alkohol u Hrvatskoj (7I3 eura/hl) je uz Bugarsku (562 eura/hl) među najnižima. Najviše stope primjenjuju se u Švedskoj (5.950 eura/hl), Finskoj (4.340 eura/hl) i u UK-u (3.36o eura/hl). Snižena stopa na etilni alkohol u EU-u primjenjuje se za "blaža" žestoka pića te u nekim regijama i za male destilerije čija je godišnja proizvodnja do Io hl čistog alkohola. Mali proizvođači jakog alkoholnog pića u Hrvatskoj su oni koji proizvode za vlastite potrebe do 20 litara čistog alkohola godišnje po kućanstvu. Porez se plaća prema zapremnini kotla (Ioo litara = Ioo kuna, veći od Ioo litara = 200 kuna). Ukoliko proizvedu veću količinu jakoga alkoholnog pića, primjenjuje se stopa trošarina kao i za ostale obveznike $(5.300 \mathrm{kn} / \mathrm{hl}$ čistog alkohola).

\footnotetext{
${ }^{2}$ Austrija, Bugarska, Cipar, Češka, Grčka, Njemačka, Italija, Luksemburg, Mađarska, Malta, Portugal, Rumunjska, Slovenija, Slovačka i Španjolska.
} 


\section{TROŠARINE NA DUHAN I DUHANSKE PROIZVODE}

Novim Zakonom usklađuju se definicije duhanskih prerađevina i visine trošarina na cigarete. Za izračun specifične trošarine promijenit će se definicija cigareta ${ }^{3}$ i postupci utvrđivanja i prijavljivanja maloprodajnih cijena duhanskih prerađevina i izjednačiti visina trošarine na cigare i cigarilose.

Sukladno Direktivama Vijeća (2010/I2/EU, 20II/64/EU i 20IO/I2/EU), umjesto maloprodajne cijene najpopularnije kategorije cigareta (Most Popular Price Category - MPPC) kao referentna vrijednost i osnova za mjerenje postotka udjela specifične trošarine $u$ ukupnom poreznom opterećenju uvodi se prosječna ponderirana maloprodajna cijena cigareta (Weighted Average Price - WAP) ${ }^{4}$ puštenih u potrošnju.

\section{Grafikon 2.}

Stope trošarina na cigarete u zemljama EU-a (I. siječnja 20I3.) u eurima, u \% od prosječno ponderirane maloprodajne cijene cigareta

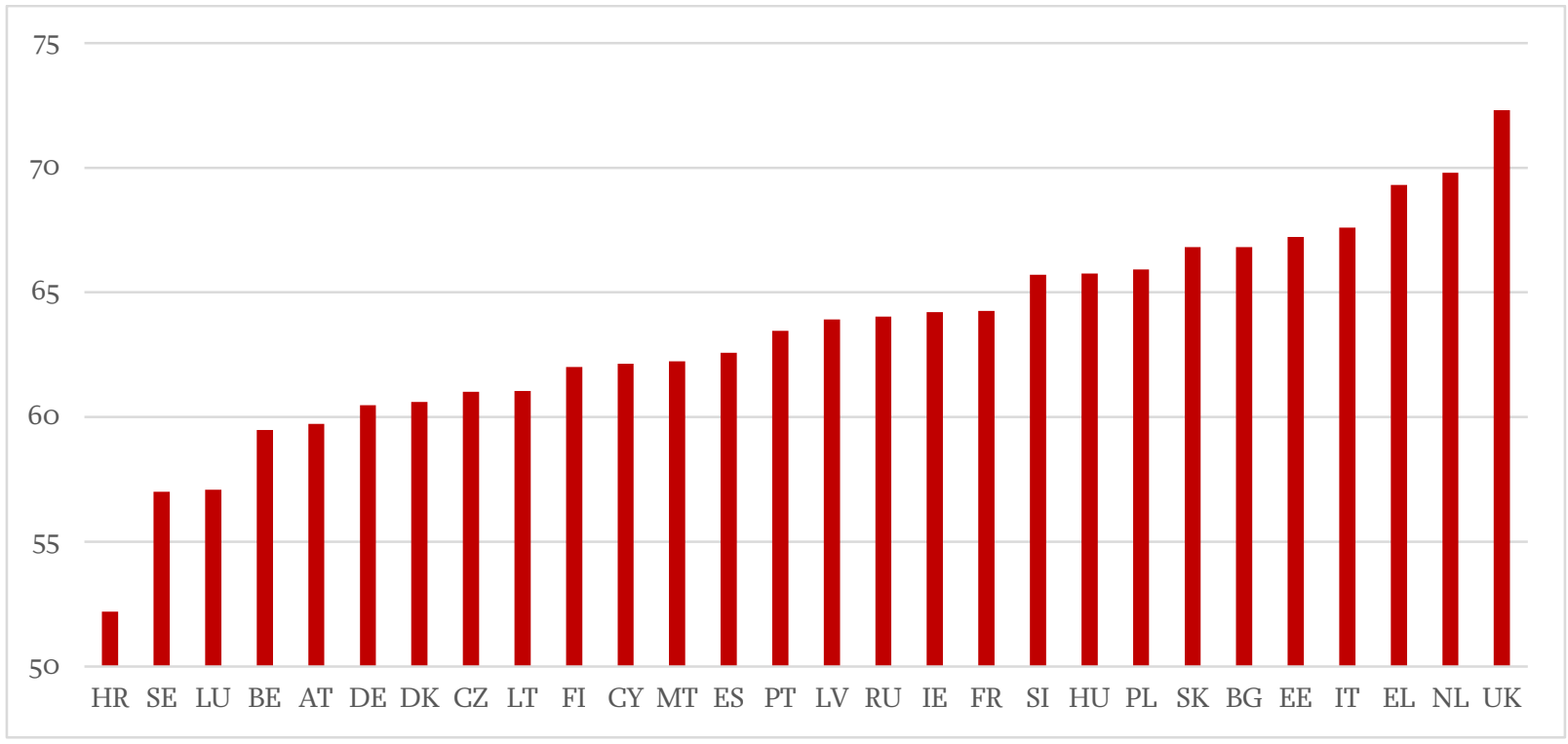

Napomena: Stopa u Hrvatskoj odnosi se na prvih II mjeseci 2012.

Izvor: European Commission (2013c)

Na grafikonu 2. je vidljivo da je stopa u Hrvatskoj najniža, pa je za usklađivanje s europskim stopama nužno dulje vremensko razdoblje. Tijekom pristupnih pregovora za ostvarenje minimalne visine trošarine, Hrvatskoj je odobreno prijelazno razdoblje do 3I. prosinca 20I7., do kada treba provesti postupno usklađivanje u najmanje tri faze. Usklađivanje stopa trošarina na cigarete započelo je već prethodnih godina, a buduće obveze su sljedeće:

- I. srpnja 20I3. - ukupna trošarina mora iznositi najmanje 57\% prosječne ponderirane maloprodajne cijene cigareta puštenih u potrošnju i 64 eura/I.ooo komada. Sada je 52,2\% i 65,25 eura/I.ooo komada cigareta (podaci za prvih II mjeseci 20I2.);

- I. siječnja 20I4. - minimalno 77 eura/I.ooo komada, bez obzira na WAP;

- 3I. prosinca 20I7. - 90 eura/I.00o komada, uz minimalno 60\% prosječne ponderirane maloprodajne cijene cigareta puštenih u potrošnju.

\footnotetext{
${ }^{3}$ U izračunu specifične trošarine, jednom će se cigaretom smatrati smotuljak duhana čija je dužina bez filtera ili usnika do $8 \mathrm{~cm}$, što je promjena s obzirom na dosad propisanih do $9 \mathrm{~cm}$. Dvjema će se cigaretama smatrati cigarete dužine od $8 \mathrm{do}$ II $\mathrm{cm}$, trima od II do I4 cm, odnosno povećava se za jednu cigaretu svaka daljnja 3 centimetra dužine smotuljka duhana bez filtera ili usnika. ${ }^{4}$ Izračunava se kao omjer između ukupne vrijednosti svih cigareta puštenih u potrošnju u 20I2. i ukupne količine cigareta puštenih u potrošnju u 2012.
} 
Direktiva propisuje jednake minimalne stope na cigare i cigarilose. Pristupanjem EU-u, trošarina na cigare i cigarilose će iznositi $600 \mathrm{kn} /$ I.ooo komada (80 eura/1.ooo komada), što u potpunosti zadovoljava kriterij minimalne trošarine (I2 eura/I.ooo komada). Višu stopu specifične trošarine na cigare imaju samo Irska (275 eura/1.ooo komada), UK (243 eura/I.ooo komada), Estonija (2II eura/I.ooo komada) i Cipar (9o eura/I.ooo komada).

Pristupanjem EU-u povećava se trošarina na sitno rezani duhan čiji rast će se nastaviti i u sljedećim godinama. Gotovo 50\%-tni rast stope očekuje se i za ostali duhan za pušenje što je u skladu s preporukama Europske komisije da zbog konkurentnosti među duhanskim proizvodima, posebice cigaretama i ostalim duhanima za pušenje (koji su jednako štetni) treba čim više izjednačavati porezno opterećenje (stope).

\section{Tablica 2.}

Stope trošarina na duhanske proizvode u Hrvatskoj i Europskoj uniji

\begin{tabular}{|c|c|c|c|c|}
\hline $\begin{array}{l}\text { Trošarinski } \\
\text { proizvod }\end{array}$ & $\begin{array}{l}\text { Visina trošarine } \\
\text { u Hrvatskoj }\end{array}$ & $\begin{array}{l}\text { Visina trošarine } \\
\text { u Hrvatskoj nakon } \\
\text { pristupanja EU }\end{array}$ & $\begin{array}{l}\text { Minimalna trošarina } \\
\text { u EU }\end{array}$ & $\begin{array}{l}\text { Minimalna } \\
\text { EU trošarina } \\
\text { izražena }(\mathbf{u} \text { kn) }\end{array}$ \\
\hline \multicolumn{5}{|l|}{ Cigarete } \\
\hline $\begin{array}{l}\text { Specifična } \\
\text { trošarina }\end{array}$ & I80 kn/I.OOO kom. & $64 € /$ I.OOO kom. & $\begin{array}{l}\text { 64 €/I.ooo kom. bez obzira } \\
\text { na WAP udio specifične } \\
\text { trošarine u ukupnom } \\
\text { poreznom opterećenju } \\
5 \text { - 76,5\%; } \\
\text { - od I. siječnja 2OI4. } \\
77 € / \text { I.ooo kom. bez obzira na } \\
\text { WAP; } \\
\text { - do 3I. prosinca 2OI7. } \\
\text { 9o eura/I.ooo kom. bez } \\
\text { obzira na WAP; udio } \\
\text { specifične trošarine u } \\
\text { ukupnom poreznom } \\
\text { opterećenju } 7,5-76,5 \% \text {. }\end{array}$ & 572 kn/1.ooo kom. \\
\hline $\begin{array}{l}\text { Proporcionalna } \\
\text { trošarina }\end{array}$ & $\begin{array}{l}36 \% \text { maloprodajne } \\
\text { cijene }\end{array}$ & $57 \%$ WAP & $\begin{array}{l}\text { 57\% udio ukupne trošarine u } \\
\text { WAP-u; } \\
\text { - od I. siječnja 2OI4. } \\
\text { 6o\% udio ukupne trošarine u } \\
\text { WAP-u; }\end{array}$ & 668 kn/1.000 kom. \\
\hline \multicolumn{5}{|l|}{ Cigare } \\
\hline & I.IOO kn/I.OOO kom. & $600 \mathrm{kn} / \mathrm{I} .000 \mathrm{kom}$. & $\mathrm{I} 2 € / \mathrm{I} .000$ kom. & 89 kn/I.OOO kom. \\
\hline \multicolumn{5}{|l|}{ Cigarilosi } \\
\hline & 220 kn/I.OOO kom. & $600 \mathrm{kn} / \mathrm{I} .000 \mathrm{kom}$. & I2 €/I.OOO kom. & $89 \mathrm{kn} / \mathrm{I} .000$ kom. \\
\hline \multicolumn{5}{|l|}{$\begin{array}{l}\text { Sitno rezani } \\
\text { duhan za } \\
\text { pušenje }\end{array}$} \\
\hline & $325 \mathrm{kn} / \mathrm{kg}$ proizvoda & 35I kn/kg proizvoda & $\begin{array}{l}\text { od I. siječnja 20I3. - 47€/kg } \\
\text { od I. siječnja 20I5. - } 54 € / \mathrm{kg} \\
\text { od I. siječnja 20I8. - } 60 € / \mathrm{kg} \\
\text { od I. siječnja 2020. - } 60 € / \mathrm{kg}\end{array}$ & $\begin{array}{l}349 \mathrm{kn} / \mathrm{kg} \\
40 \mathrm{I} \mathrm{kn} / \mathrm{kg} \\
446 \mathrm{kn} / \mathrm{kg} \\
446 \mathrm{kn} / \mathrm{kg}\end{array}$ \\
\hline \multicolumn{5}{|l|}{$\begin{array}{l}\text { Ostali duhan } \\
\text { za pušenje }\end{array}$} \\
\hline & I46 kn/I.0Oo kom. & 296 kn/I.OOo kom. & $22 € / \mathrm{kg}$ & I63 kn/I.Ooo kom. \\
\hline
\end{tabular}

Izvor: European Commission (2013c); Zakon o trošarinama 


\section{TROŠARINE NA ENERGENTE I ELEKTRIČNU ENERGIJU}

Najveće promjene u sustavu trošarina odnose se na energente i električnu energiju. Osim povećanja stopa, uvodi se i oporezivanje prirodnog plina, ugljena, koksa i električne energije.

Sustav oporezivanje energenata u EU-u je najsloženiji - i prema broju oporezivih proizvoda, broju i visini stopa te nizu izuzeća i posebnosti u pojedinim zemljama. Osim harmoniziranih trošarina na energente, 8 zemalja $^{5}$ je uvelo i posebna (parafiskalna) davanja i naknade na neke vrste energenata. Osim fiskalnih, sve značajniji razlozi oporezivanja energenata su ekološki što je utjecalo na rast i sve veću diferencijaciju stopa. Svim zemljama - uključujući i Hrvatsku - zajedničko je da najveći udio u ukupno naplaćenim trošarinama imaju upravo prihodi od trošarina na energente.

Iz tablice 3. je vidljivo da su sve stope uglavnom usklađene s minimalno propisanima, osim što su niže na UNP i prirodni plin koji služe kao pogonsko gorivo. Povećat će se stope na plinsko ulje za pogonsko gorivo (4\%) i na kerozin - petrolej (9\%). No, ne treba zaboraviti da su od I. siječnja 20I3. Uredbom o visini trošarine na motorne benzine, plinsko ulje i kerozin za pogon (NN I44/I2) - uz ostale - povećane i te trošarine (I5\% i 2\%). Iako u EU-u minimalno propisana trošarina na kerozin namijenjen grijanju ima stopu o\%, novim se Zakonom uvodi oporezivanje od I.752 kn/I.ooo l. Najveća se promjena odnosi na uvođenje oporezivanja prirodnog plina, ugljena, koksa i električne energije, kod kojih su stope uglavnom na razini minimalnih, a više su na prirodni plin namijenjen grijanju. U Zakonu su propisana stanovita oslobođenja za uporabu energenata i električne energije za određene namjene. Najznačajnija se odnose na prirodni plin i električnu energiju koji se koriste u kućanstvima te na plin za pogon. Člankom Ioı. reguliraju se i oslobođenja vezana uz:

- uporabu prirodnog plina i električne energije u pojedinim industrijskim procesima te na električnu energiju dobivenu iz obnovljivih izvora energije (ukoliko je proizvođač koristi za vlastite potrebe);

- energente koji se koriste kao pogonsko gorivo za plovidbu, uključujući ribolov i električnu energiju proizvedenu na plovilu (osim uporabe plovnih objekata i plovila za privatne svrhe);

- energente koji se koriste kao gorivo u zračnom prometu (osim uporabe za privatne letove);

- i dalje se primjenjuju postojeća oslobođenja za dizelsko gorivo (plavi dizel) namijenjeno poljoprivredi, ribarstvu i u akvakulturi, uz uvođenje oslobođenja na označeno plinsko ulje za pogonsko gorivo u nacionalnoj komercijalnoj plovidbi na međunarodnim linijama, domaćim vodama i unutar države članice.

${ }^{5}$ Belgija, Cipar, Njemačka, Nizozemska, Finska, Švedska, Ujedinjeno Kraljevstvo i Litva. 
Tablica 3.

Stope trošarina na energente i električnu energiju u Hrvatskoj i Europskoj uniji

\begin{tabular}{|c|c|c|c|c|}
\hline Trošarinski proizvod & $\begin{array}{l}\text { Visina trošarine } \\
\text { u Hrvatskoj }\end{array}$ & $\begin{array}{l}\text { Visina trošarine u } \\
\text { Hrvatskoj nakon } \\
\text { pristupanja EU-u }\end{array}$ & $\begin{array}{l}\text { Minimalna } \\
\text { trošarina u EU }\end{array}$ & $\begin{array}{l}\text { Minimalna } \\
\text { EU trošarina } \\
\text { izražena u kunama }\end{array}$ \\
\hline \multicolumn{5}{|l|}{ Motorni benzin - pogonska goriva } \\
\hline $\begin{array}{l}\text { olovni } \\
\text { bezolovni }\end{array}$ & $\begin{array}{l}3.8 \mathrm{OI} \mathrm{kn/I.OOO} \mathrm{l} \\
3.15 \mathrm{kn} / \mathrm{I} .0001\end{array}$ & & $\begin{array}{l}42 \mathrm{I} € / \mathrm{I} .0001 \\
359 € / \mathrm{I} .0001\end{array}$ & $\begin{array}{l}3.126 \mathrm{kn} / \mathrm{I} .000 \mathrm{l} \\
2.666 \mathrm{kn} / \mathrm{I} .000 \mathrm{l}\end{array}$ \\
\hline \multicolumn{5}{|l|}{ Plinsko ulje (dizel) } \\
\hline $\begin{array}{l}\text { za pogon } \\
\text { za grijanje } \\
\text { industrijska i komercijalna uporaba* }\end{array}$ & $\begin{array}{l}2.354 \mathrm{kn} / \text { I.OOO l } \\
343 \mathrm{kn} / \text { I.OOO l }\end{array}$ & $2.450,50 \mathrm{kn} / \mathrm{I} .000 \mathrm{l}$ & $\begin{array}{l}330 € / \mathrm{I} .000 \mathrm{l} \\
2 \mathrm{I} € / \mathrm{I} .0001 \\
2 \mathrm{I} € / \mathrm{I} .000 \mathrm{l}\end{array}$ & $\begin{array}{l}2.450 \mathrm{kn} / \mathrm{I} .0001 \\
\text { I56 kn/I.OOO } 1 \\
156 \mathrm{kn} / \text { I.OOO } 1\end{array}$ \\
\hline \multicolumn{5}{|l|}{ Kerozin - petrolej } \\
\hline $\begin{array}{l}\text { za pogon } \\
\text { za grijanje } \\
\text { industrijska i komercijalna uporaba }\end{array}$ & $2.243 \mathrm{kn} / \mathrm{I} . \mathrm{OOO} \mathrm{l}$ & $\begin{array}{l}2.450,50 \mathrm{kn} / \mathrm{I} .0001 \\
\text { I.752 kn/I.OOO l }\end{array}$ & $\begin{array}{l}330 € / \mathrm{I} .000 \mathrm{l} \\
\mathrm{O} € / \mathrm{I} . \mathrm{OOOO} 1 \\
2 \mathrm{I} € / \mathrm{I} .000 \mathrm{l}\end{array}$ & $\begin{array}{l}2.450 \mathrm{kn} / \mathrm{I} .000 \mathrm{l} \\
\text { o kn } \\
156 \mathrm{kn} / \mathrm{I} .000 \mathrm{l}\end{array}$ \\
\hline \multicolumn{5}{|l|}{ UNP - ukapljeni naftni plin } \\
\hline $\begin{array}{l}\text { za pogon } \\
\text { za grijanje (poslovna/neposlovna) } \\
\text { industrijska i komercijalna uporaba }\end{array}$ & $\begin{array}{l}\text { 912,50 kn/1.00O kg } \\
\text { o kn/1.000 kg }\end{array}$ & $\begin{array}{l}\text { IOO kn/1.0OO kg } \\
\text { IOO kn/1.00O kg }\end{array}$ & $\begin{array}{l}\mathrm{I} 25 € / \mathrm{I} .000 \mathrm{~kg} \\
\mathrm{O} € \\
4 \mathrm{I} € / \mathrm{I} .000 \mathrm{~kg}\end{array}$ & $\begin{array}{l}928 \mathrm{kn} / \mathrm{I} .000 \mathrm{~kg} \\
\mathrm{O} \mathrm{kn} \\
304 \mathrm{kn} / \mathrm{I} .000 \mathrm{~kg}\end{array}$ \\
\hline \multicolumn{5}{|l|}{ Teško loživo ulje - za grijanje } \\
\hline $\begin{array}{l}\text { poslovno } \\
\text { neposlovno } \\
\text { biogoriva - čista } \\
\end{array}$ & $160 \mathrm{kn} / \mathrm{I} .000 \mathrm{~kg}^{6}$ & o kn & $\begin{array}{l}\text { I5 } € / \text { I.OOO kg } \\
\text { I5€/I.00O kg }\end{array}$ & $\begin{array}{l}\text { III kn/I.OOO kg } \\
\text { III kn/I.OOO kg }\end{array}$ \\
\hline \multicolumn{5}{|l|}{ Prirodni plin } \\
\hline $\begin{array}{l}\text { za pogon } \\
\text { za grijanje } \\
\text { - neposlovna uporaba } \\
\text { za grijanje } \\
\text { - poslovna uporaba } \\
\text { industrijska i komercijalna uporaba } \\
\end{array}$ & & $\begin{array}{l}\mathrm{o} \mathrm{kn} / \mathrm{MWh} \\
8, \mathrm{Io} \mathrm{kn} / \mathrm{MWh}^{7} \\
(29,6 \mathrm{kn} / \mathrm{GJ}) \\
4,05 \mathrm{kn} / \mathrm{MWh} \\
(\mathrm{I} 4,6 \mathrm{kn} / \mathrm{GJ}) \\
\text { ooo }\end{array}$ & $\begin{array}{l}0, \mathrm{I} 5 € / \mathrm{GJ} \\
0,3 € / \mathrm{GJ}\end{array}$ & $\begin{array}{l}\text { I9 kn/GJ } \\
2,23 \mathrm{kn} / \mathrm{GJ} \\
\text { I,II kn/GJ } \\
2,23 \mathrm{kn} / \mathrm{GJ}\end{array}$ \\
\hline \multicolumn{5}{|l|}{ Ugljen i koks } \\
\hline $\begin{array}{l}\text { neposlovna uporaba } \\
\text { poslovna uporaba }\end{array}$ & & $\begin{array}{l}2,30 \mathrm{kn} / \mathrm{GJ} \\
2,30 \mathrm{kn} / \mathrm{GJ} \\
\end{array}$ & $\begin{array}{l}\mathrm{O}, 3 € / \mathrm{GJ} \\
\mathrm{O}, \mathrm{I} 5 € / \mathrm{GJ}\end{array}$ & $\begin{array}{l}2,23 \mathrm{kn} / \mathrm{GJ} \\
\mathrm{I}, \mathrm{II} \mathrm{kn} / \mathrm{GJ}\end{array}$ \\
\hline \multicolumn{5}{|l|}{ Električna energija } \\
\hline $\begin{array}{l}\text { neposlovna uporaba } \\
\text { poslovna uporaba }\end{array}$ & & $\begin{array}{l}\text { 7,50 kn/MWh } \\
3,75 \mathrm{kn} / \mathrm{MWh}\end{array}$ & $\begin{array}{l}\text { I } € / M W h \\
0,5 \text { EUR/MWh }\end{array}$ & $\begin{array}{l}\text { 7,43 kn/MWh } \\
\text { 3,7I kn/MWh }\end{array}$ \\
\hline
\end{tabular}

* osim za poljoprivredu

Izvor: European Commission (2013b); Zakon o trošarinama.

$\mathrm{Na}$ grafikonu 3. prikazane su maksimalne trošarine na olovni i bezolovni benzin. U europskim se zemljama na isti proizvod primjenjuju različite stope, ovisno o udjelu sumpora, $\mathrm{CO}_{2}$, biogoriva, te o namjeni ili regiji u kojoj se gorivo koristi. U Poljskoj, Sloveniji i Finskoj korištenje olovnog benzina je zabranjeno. Četiri EU zemlje imaju niže stope na olovni benzin od hrvatskih, a najviše stope su u Nizozemskoj, UK-u i Švedskoj. U Hrvatskoj će se plinsko ulje (dizelsko gorivo) za pogon oporezivati minimalnom stopom (330 eura/r.ooo l), koja je najniža u EU-u. Neke zemlje - kao i Hrvatska - iskoristile su mogućnost primjene snižene stope za dizelsko gorivo koje se koristi u nekim sektorima (poljoprivreda, ribarstvo, hortikultura, šumarstvo, željeznički promet). Stopa trošarine na kerozin koji se koristi kao pogonsko gorivo će se danom pristupanja EU-u izjednačiti s minimalnom (330 eura/I.ooo l), a uvodi se i oporezivanje kerozina za grijanje (I.752 kn/I.ooo l) i UNP-a za grijanje. Iako Direktiva predviđa nultu stopu za kerozin i UNP namijenjen grijanju, uglavnom sve EU zemlje oporezuju ove proizvode. Minimalna stopa na prirodni plin koji se koristi kao pogonsko gorivo je 2,6 eura/GJ. U novom Zakonu ova stopa nije usklađena s Direktivom,

\footnotetext{
${ }^{6}$ Iako su proizvodi po Kombiniranoj nomenklaturi isti kao u Direktivi, u ZOT-u nije navedeno radi li se o grijanju za poslovne ili neposlovne namjene.

${ }^{7}$ Preračunato I MWh = 3,6 GJ.
} 
odnosno iznosi o kn/MWh, što nije jednako izuzeću u čl. IOI. (8). Minimalna stopa u zemljama EU-a na plin namijenjen grijanju (poslovna uporaba) iznosi o,I5 eura/GJ i kreće se u rasponima od o do 9,37 eura/GJ. Minimalna stopa na poslovnu uporabu električne energije iznosi o,5 eura/MWh, a za neposlovnu I euro/MWh. Stope su najviše u Nizozemskoj (II6 eura/MWh) i Danskoj (94-IIo eura/MWh). Pristupanjem EU-u, stope će u Hrvatskoj biti jednake minimalnim stopama. I kod oporezivanja električne energije postoji mogućnost primjene sniženih stopa za određene sektore.

\section{Grafikon 3.}

Maksimalne trošarine na benzin (olovni i bezolovni) u zemljama Europske unije (€/I.ooo l)

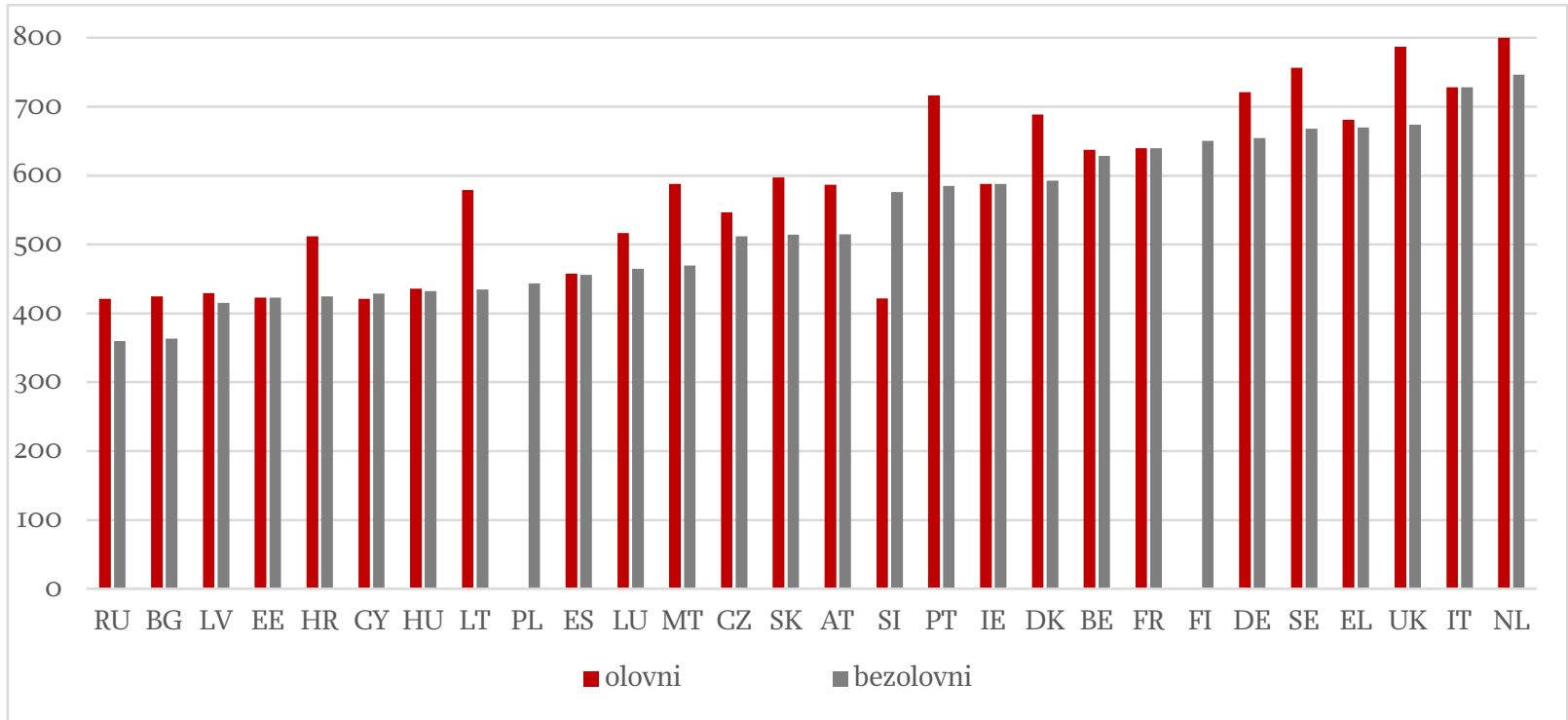

Izvor: European Commission (20I3.c); Zakon o trošarinama

\section{ZAKLJUČAK}

Premda su novim Zakonom o trošarinama stope trošarina u najvećem dijelu usklađene s minimalnim stopama propisanim Direktivama, u budućnosti nas očekuje daljnji porast stopa (na cigarete i sitno rezani duhan za pušenje). Osim opće (jedne) stope koja se primjenjuje na trošarinske proizvode $u$ Hrvatskoj $u$ EU-u postoje razlike $i \mathrm{u}$ broju stopa, pa se na iste proizvode - pod određenim uvjetima - primjenjuju i snižene stope. U oporezivanju energenata neusklađene su (niže) stope na UNP i prirodni plin za pogon. Direktiva 2003/96/EU propisuje da se energenti (plinsko ulje - dizel, kerozin - petrolej, UNP i prirodni plin) namijenjeni industrijskoj i komercijalnoj uporabi oporezuju, što novi Zakon o trošarinama zasad ne propisuje.

Međutim, ako je i zadovoljen uvjet minimalnih stopa propisanih Direktivama EU-a, Vlada RH može prema Zakonu o trošarinama (čl. 6o, toč. 7) uredbom mijenjati (povećavati) propisane stope trošarina. Ovisno o ciljevima i potrebama fiskalne politike (manjak proračunskih prihoda, rast javnih rashoda, rast javnog duga i sl.), stope se mogu mijenjati.

Svako povećanje poreza utječe na cijenu oporezivih proizvoda pa je stoga moguće očekivati rast cijena cigareta, ostalog duhana i energenata. Manje zabrinjava porast cijena cigareta, ali porast cijena energenata - unatoč nekim oslobođenjima - znatno će utjecati na opći rast cijena, životni standard građana i poslovanje gospodarskog sektora.

Prema okvirnoj procjeni Ministarstva financija, uvođenje trošarine na električnu energiju trebalo bi utjecati na povećanje maloprodajne cijene za I,O5\%, a za prirodni plin 3,41\% (krajnji 
kupci priključeni na transportni sustav), odnosno za 2,38\% (krajnji kupci priključeni na distribucijski sustav).

Kada se govori o utjecaju na cijene, osim trošarina treba imati na umu i PDV koji se obračunava na maloprodajnu cijenu. Stopa PDV-a u RH jedna je od najviših u EU-u i - što je još važnije - viša je od stopa u susjednim zemljama (osim Mađarske). I uz nižu trošarinu, cijene trošarinskih proizvoda u Hrvatskoj mogu biti više, što potiče legalnu, ali i ilegalnu prekograničnu kupovinu, a time i smanjenje poreznih prihoda. Novi Zakon o trošarinama donosi i nove, detaljnije odredbe o provedbi nadzora (učinkovitiji pravni okvir za suzbijanje, sprečavanje i sankcioniranje nezakonitosti i porezne evazije) i obuhvatnije mjere i aktivnosti u sprečavanju prekršajnih djela i kažnjavanju počinitelja. Ipak, legalna prekogranična kupovina jeftinijih proizvoda u susjednim zemljama može utjecati na porezne prihode.

\section{LITERATURA}

Council Directive 2003/96/EC of 27 October 2003 restructuring the Community framework for the taxation of energy products and electricity.

Council Directive 2OIO/I2/EU of I6 February 20Io amending Directives 92/79/EEC, 92/80/EEC and 95/59/EC on the structure and rates of excise duty applied on manufactured tobacco and Directive 2008/II8/EG.

Council Directive 2OII/64/EU of 2I June 2OII on the structure and rates of excise duty applied to manufactured tobacco.

Council Directive 92/84/EEC of 19 October 1992 on the approximation of the rates of excise duty on alcohol and alcoholic beverages.

European Commission, 20I3a. Excise Duty Tables Part I - Alcoholic Beverages [online]. Dostupno na <http://ec.europa.eu/taxation_customs/taxation/excise_duties/ alcoholic_beverages/rates/> [20.3. 2013.]

European Commission, 2013b. Excise Duty Tables Part II - Energy Products and Electricity [online]. Dostupno na <http://ec.europa.eu/taxation_customs/resources/documents/ taxation/excise_duties/energy_products/rates/excise_dutiespart_ii_energy_products_en.pdf $>$ [20.3. 2013.]

European Commission, 20I3c. Excise Duty Tables Part III - Manufactured Tobacco [online]. Dostupno na <http://ec.europa.eu/taxation_customs/resources/documents/taxation/ excise_duties/tobacco_products/rates/excise_duties-part_iii_tobacco_en.pdf> [20.3. 2013.]

The Brewers of Europe, 2012. Excise Duty Rates for Beer in Europe [online]. Brussels: The Brewers of Europe. Dostupno na <http://www.brewersofeurope.org/docs/publications/ BED2OI2.pdf> [20. 3. 2OI3.]

Uredba o visini trošarine na motorne benzine, plinsko ulje i kerozin za pogon, NN,I44/I2. Zagreb: Narodne novine.

Zakon o trošarinama, NN 83/o9, 3/12, 22/13. Zagreb: Narodne novine. 